\title{
Understanding Young People's Political Engagement in Niger Delta Nigerian
}

\author{
Bari-ika Nornubari Vite \\ Anglia Ruskin University, Chelmsford, UK
}

\begin{abstract}
The study focuses on the way Niger Delta youth participation in policies is formed through the ideas of youth citizenship. In this research, it will explore the current text and recognized means of comprehending youth participation that acknowledge the modern democracy. It will give attention to research that addresses the process through which young lives participate in democracy and why they do not. It considers the issues that either hinder or promote engagement with young peoples and the way that is affected by some groups in context and practice. It explores the proposition of a new paradigm shift in the human development approach in engagement that identifies and reveals that political literacy and party expectation among politicians are less concerning Nigeria youth and that some small numbers unite with political gatherings, organizations, and other official political associations.
\end{abstract}

Keywords: civil-minded, education, obligatory, structure, programs

\section{Introduction}

The study focuses on the way Niger Delta youth participation in policies is formed through the ideas of youth citizenship. In this research, it will explore the current text and recognized means of comprehending youth participation that acknowledge the modern democracy. It will give attention to research that addresses the process through which young lives participate in democracy and why they do not.

Thus, the various challenging issues affect the process and the comprehending of political participation. Ganesh and Zoller (2012) emphasized that political involvement has reappeared in modern days through the changes in representation and dynamic inclusion of organization to form more activities for political engagement, these processes of activities are sometimes demonstrated to express political thoughts and targets and political representatives' objectives (Norris, 2003).

Thus, this assertion has a substantial impact on the study of participation and politics. However, Marsh (2011) claimed that some modern politicians have taken it easy by not responding in time to political engagement. Now, attention will be placed on the works of Marsh and colleagues who argued that studies on youth participation have been ineffective in taking the challenges of understanding, how political participation would be changed, and viewing its influence on modern democracy. The author will explore some literature from Nigeria and Africa and other countries to recognize fundamental questions that are prominent to this study. Thus, the principles of governance present more reflection of these modifications. However, minus consideration is made to the type of groups, actors that aims at youth political individualities.

Bari-ika Nornubari Vite, research associate, Faculty of Health, Social Care and Education, Anglia Ruskin University. 
Researchers on e-political participation have given more attention to the process of civic involvement which is changing and been viewed by youth on e-practices to comprehend the nature and impact of this transformation. Meanwhile, the debates continue either to disconnect or to strengthen e-participation of those who are civil-minded (Ganesh \& Zoller, 2012; Norris, 2003). The debates now move to explore the way various groups practice e-political participation as well as e-practices consideration that fosters civic engagement (J. Brown, 2012; S. Brown, 2015; Vromen, Loader, Xenos, \& Bailo, 2016). Thus, this study gives many insights on wider study of youth participation. Moreover, the mainstream scrutinizes and mends to straighten e-practise as the background for broader choice of individual and community deeds.

Thus, attention will be given to three aspects of new political involvement: what underpins awareness of democratic foundations, the state function, as well as engagement of collective political life. By considering these three characteristics of political identity, it will be good to recognize how some scholars vary in their methodologies toward the analysis of citizenship and by the process that accolades and expands how to explore and conceptualize youth participation.

\section{Concern for Researching Youth Participation}

In focusing on youth participation in Nigerian democracies, there is evidence of low turn-out of some practices of political participation. Low intensities of voter turn-out (Holbein \& Hillygus, 2015), party membership (Chai \& Ngai, 2016), and confidence in governments and politicians have all indicated difficulties of democracy. Additionally, there is proof that these tendencies are more noticeable amongst youth in Niger Delta Nigeria (Norris, 2003).

In Nigeria, the study on young people's behaviors and mindsets identifies poor turn-out on levels of participation and commitment to political gatherings and reduces the numbers of youth that vote and consider electoral membership as civic responsibility (Cushing, 2015). The most important idea is that the youth associates do not show concern for politics or democracy. Burbank and Goldsmith (n.d.) had argued that youth at the age of around 21 in 2000 have turned their back on formal political practices and organizations, like political gatherings and elections (Anderson \& Beramendi, 2012). However, they notice that this associate is making the plan to take actions on issues that they are concerned about, as less percentage of young people's engagement in events like join charity for purposes, as this suggests their political neutrality (Cairney, 2015). It is also found that young people are unconvinced of the political structure in the region or country, notwithstanding the fact that democratic process and electorate are developing (Bennett, 2014). In disparity to Anderson and Beramendi (2012), the argument upholds that youth are not indifferent, and they are disenchanted because of the insensitivities of government officials and the political systems (Cairney, 2015; Bennett, 2014).

In Nigeria, the study of political engagement is centered on structures of involvement in conventional party-political setting, like election (Boffi, 2012), political elites (Doorenspleet, 2012), types of political comprehension and the productiveness of civic knowledge (Doorenspleet, 2012; Cushing, 2015), and representatives of community groups (Brown, 2012). There has been the historical concentration of borough and citizenship education that has been reflected on some analyses (Zuckerman, 2014; Wurgler \& Brooks, 2014), which end with the civic discrepancy that may be corrected via civic and democratic education. However, the research takes a normative practice to involvement and centre on how traditional structures of party-political engagement may be fostered. As youth political engagement has been discussed, with few 
concessions, attention is on political literacy (Wurgler \& Brooks, 2014; Boffi, 2012; List, Luskin, Fishkin, \& McLean, 2013; Zuckerman, 2014), electoral engagement (Burbank \& Goldsmith, n.d.; Corvalan \& Cox, 2013; Holbein \& Hillygus, 2015; Smith, 2016), and views of citizenship, politicians, and governments (Bessell, 2011; Flores-Macias, 2012; Hayes, 2013; Corvalan \& Cox, 2013). Research revealed that party-political literacy and expectation in politicians are less between Nigeria youth and that most small numbers unite with political gatherings, organizations, and other official political associations (Brown, 2012; Vromen et al., 2016). Since voting is obligatory, Nigeria shows good intensities of all age group engagement compared to nations with non-obligatory organizations in Africa. Furthermore, Nigeria Electoral Commission has anticipated that about $80 \%$ of young lives of $18-25$ have registered for election.

In Nigerian environments, these methods of understanding youth engagement and politics can be disparaged on two grounds: firstly, limited ideas of political engagement, and secondly, considerations of the Internet function of political engagement.

\section{The Finite Ideology of Party-Political Involvement in Nigeria}

There has been critique of the mainstream current text for captivating partial normative idea of political engagement (O'Toole, 2003; Vromen et al., 2016; List et al., 2013; Marsh, O’Toole, \& Jones, 2007; Glucksberg, 2014). However, some studies have admitted that youth ideology in politics and engagement varies (Bachche, 2015; Catlaw \& Treisman, 2014; Flores-Macias, 2012). The propensity in this literature is to indicate that youth are not engaging in conventional structure engagement and the reason is that they are either apathetic or inadequately informed or socialised (Kusakabe, 2014).

Critics of the mainstream current text on young people's engagement of party-politics argument are that it does not interprete into record and comprehending. Thus, the approaches used in coordinating new organizations were targeted at electoral engagement, in order to attribute to political ideas and the exercises of youth engagement (Vromen et al., 2016; Marsh, 2011). Perhaps, to an extent, based on the fact, some studies are qualitative and use analyses to evaluate views and objectives. Thus, the issue is that the analysed study may not be difficult itself, rather is the structure and references used in the consideration that matters. For example, although notwithstanding the classifying non-traditional structures of engagement that emerges from social activities, such as demonstrations as well as protests (Martinez, Loyola, \& Cumsille, 2015). Some of the literature indicated that youth who do not participate in predetermined structures of engagement are inactive (Miles, 2015) or disengaged (Checkoway, 2011). And some modern research has notably expanded the definition of engagement (Checkoway, 2011), as such, they are unsuccessful to explore youth own ideas on politics and engagement, rather measuring youth behaviour against "adult-centric ideas of participation" (Blanchet-Cohen, Manolson, \& Shaw, 2014, p. 22).

The limited consideration of youth views on engagement shows two connected analyses: That non-engagement is associated with indifference (O'Toole, Lister, Marsh, Jones, \& McDonough, 2003) as well as exclusion of novel structure of engagement involving the emerging engagement procedures. However, the structures like young people's committees, advisory panels, and representative functions are the focus of the study of effective engagement policies, which are seldom and apparently viewed within the conventional text of political engagement. However, it is put in the category of volunteering. Furthermore, some young people do not view participatory acts as volunteering. Therefore, it is possible that some young people's forms of membership may be dropping. 
Again, non-engagement is hardly viewed as governmental exploit, and the participation in the non-traditional structure of demonstration of political engagement is recognized with young people in Niger Delta, as they seem to abandon base on unconstructive connection toward the electorate (Anderson \& Beramendi, 2012). The research identifies youth as citizen apprentices and comprehends non-engagement as lack of success in socialization. The supposition that non-engagement equates to ignorance or apathy casts back on an individual method to youth democracy. The research takes a developmental method to young people, as it explores youth electoral engagement across transformations.

Eventually, the challenges of this method of studying young people's engagement are that new political ideology and viewpoints are missing (Mierina \& Koroleva, 2015). The contradiction to the tune of non-involvement is fostered by methods that turn down the training of youth as a phase of transformation to maturity rather than explore youth practice from a generational perception (McGarry, 2015). It indicates that research must report different socio-political, socio-cultural, high-tech, and economic surroundings by which young lives are considered and in what ways youth conceptualize and react to part-politics and governments (Marsh et al., 2007). In principle, some studies have commenced in this field (Marsh et al., 2007). In this research, youth-centered and qualitative methods were used to consider youth ideology and experiences of engagement and elucidate why young lives are regarded as non-engaging from traditional structure of party-political engagement. However, there is a debate regarding the type and extent of modifications of political participation in current democracies. It was also recognized that there are some doubts about changes in conventional approaches to political engagement which has taken place (Norris, 2003).

\section{Description of Human Development in Political Participation}

A further criticism of mainstream studies of youth political engagement is that they did not recognize the function that human development performed in determining the nature as well as the structures of collective relationships that reinforce political vantage and activities. In other to explore the current text on young lives use of human development to participation, it is appealing to elucidate what the understanding of human development as well as participation means in this context. The United Nation Development Report (2015) and Bakhru and Grant (n.d.) suggested that capability is achievable by information and engagement and could be comprehended as organizations. Organizations have three essential elements: the attractions, the activities, and the social arrangements (based on Kusakabe, 2014)

Furthermore, to have a good comprehension of the impact of human's development, this study takes into consideration how youth negotiate social structures (O’Dwyer, Lyons, \& Cohrs, 2015). As literature, the study of young people and human development is diverse and comes to view from different disciplines, such as sociology, anthropology, communication studies, philosophy, and education.

Thus, there are different epistemological, suppositional, and empirical methodologies that produce diverse ideologies on the impact of human development to youth participation. Thus, some studies look widely at human development (Vorhaus, 2015) and others explore particular capability, such as the human freedom, while others view it as everyday practices (Rodríguez López, Andreouli, \& Howarth, 2015), meetings, debate, and social relations (Rowe, 2015), and activity (Vorhaus, 2015). Moreover, while quick development in human capital has impacts on the experience of young people, the author has taken into account the critical role of human development in the context of the youth experience. From this point, the author will mostly mention development. 


\section{Conclusion}

As study in Nigeria, Africa, and United Kingdom, it notably supported the comprehension and functions that human development performs for young lives, political involvement, as well as citizenship. However, this study is not yet integrated and acknowledged by conventional studies. For instance, general studies like Galliott (2015) and Marsh et al. (2007) make reference to development in areas of transitory.

Development is often seen as means to lengthen current political structures. Thus, due attention is not given to avenues where youth are involved in acknowledging issues. Furthermore, the works on youth practice to development for involvement and underpinning which absorbs the expansion into wider studies of youth participation can foster participatory approaches and activism. The capability approach by United Nation development programs in Nigeria and Africa highlights the significance of understanding and integrating human development in conventional studies of political involvement. Thus, the hypothetical and pragmatic confrontations of the way "e-participation" in youth development are conceived.

\section{References}

Anderson, C. J., \& Beramendi, P. (2012). Left parties, poor voters, and electoral participation in advanced industrial societies. Comparative Political Studies, 45(6), 714-746.

Anderson, C., \& Norris, P. (2000). Critical citizens: Global support for democratic governance. The American Political Science Review, 94(3), 748.

Bachche, S. (2015). Deliberation on design strategies of automatic harvesting systems: A survey. Robotics, 4(2), 194-222.

Bakhru, A., \& Grant, R. (n.d.). Building capability systems in new businesses: The role of capability architecture. SSRN Electronic Journal. Retrieved from https://papers.ssrn.com/sol3/papers.cfm?abstract_id=2576531

Bang, H. P. (2010). Govern mentality and the political (system). Administrative Theory \& Praxis, 32(2), 262-268.

Bang, H. P. (2007). Governing as governance (J. Kooiman, Ed.). Public Administration, 85(1), 227-231.

Bennett, I. A. B. (2014). Elections, violence and the democratic process in Jamaica 1944-2007 by Amanda Sives, and exceptional violence: Embodied citizenship in transnational Jamaica by Deborah A. Thomas. Caribbean Studies, 42(1), 261-265.

Bessell, S. (2011). Participation in decision-making in out-of-home care in Australia: What do young people say? Children and Youth Services Review, 33(4), 496-501.

Blanchet-Cohen, N., Manolson, S., \& Shaw, K. (2014). Youth-led decision making in community development grants. Youth \& Society, 46(6), 819-834.

Boffi, M. (2012). Politicians as cultural selectors: Favouring or discouraging youth participation. Human Affairs, 22(3), 325-334.

Brown, J. (2012). Citizens fit for the 21st century? The role of school design in facilitating citizenship and self-governance in young people. Education, Citizenship and Social Justice, 7(1), 19-31.

Brown, S. (2015). Addiction, development and beyond: The new behavioural neuroscience opportunities. Drug and Alcohol Review, 34(Suppl. 1), E2-E2.

Burbank, M., \& Goldsmith, M. (n.d.). Targeting voters: Citizens and partisan get-out-the-vote efforts. SSRN Electronic Journal. Retrieved from http://ssrn.com/abstract $=1581765$

Cairney, P. (2015). Scotland's future political system. The Political Quarterly, 86(2), 217-225.

Catlaw, T., \& Treisman, C. (2014). Is “man" still the subject of administration? Administrative Theory \& Praxis, 36(4), 441-465.

Chai, J., \& Ngai, E. (2016). Decision model for complex group argumentation. Expert Systems with Applications, 45, $223-233$.

Checkoway, B. (2011). What is youth participation? Children and Youth Services Review, 33(2), 340-345.

Corvalan, A., \& Cox, P. (2013). Class-biased electoral participation: The youth vote in Chile. Latin American Politics and Society, 55(3), 47-68.

Cushing, D. F. (2015). Promoting youth participation in communities through youth master planning. Community Development, $46(1), 43-55$.

Doorenspleet, R. (2012). Critical citizens, democratic support and satisfaction in African democracies. International Political Science Review, 33(3), 279-300. 
Flores-Macias, G. (2012). Book review: Voice and vote: Decentralization and participation in Post-Fujimori Peru. Comparative Political Studies, 45(7), 935-939.

Galliott, N. (2015). Youth aspirations, participation in higher education and career choice capability: Where to from here? The Australian Educational Researcher, 42(2), 133-137.

Ganesh, S., \& Zoller, H. (2012). Dialogue, activism, and democratic social change. Communication Theory, 22(1), 66-91.

Glucksberg, L. (2014). Fairness, class and belonging in contemporary England by Katherine Smith. American Anthropologist, $116(4), 892-893$.

Hayes, N. (2013). Counting civil society: Deconstructing elite participation in the provincial English city, 1900-1950. Urban History, 40(2), 287-314.

Holbein, J. B., \& Hillygus, D. S. (2015). Making young voters: The impact of preregistration on youth turnout. American Journal of Political Science, 60(2), 364-382.

Howard, P. (2014). Participation, civics and your next coffee maker. Policy \& Internet, 6(2), 199-201.

Kusakabe, E. (2014). Daniel P. Aldrich, Building Resilience: Social Capital in Post-Disaster Recovery, University of Chicago Press, 2012. Japanese Journal of Political Science, 15(1), 153-155.

List, C., Luskin, R. C., Fishkin, J. S., \& McLean, I. (2013). Deliberation, single-peakedness, and the possibility of meaningful democracy: Evidence from deliberative polls. The Journal of Politics, 75(1), 80-95.

Marsh, D. (2011). Late modernity and the changing nature of politics: Two cheers for Henrik Bang. Critical Policy Studies, 5(1), 73-89.

Marsh, D., \& Furlong, P. (2002). A skin, not a sweater: Ontology and epistemology in political science. In D. Marsh and G. Stoker (Eds.), Theory and methods in political science. Houndsmills: Palgrave Macmillan.

Marsh, D., O’Toole, T., \& Jones, S. (2007). Young people and politics in the United Kingdom: Apathy or alienation? Hampshire, UK: Palgrave Macmillan.

Martinez, M. L., Loyola, L. I., \& Cumsille, P. (2015). Quality of participation in youth organizations: Relationships with identity and sense of sociopolitical control. Youth \& Society, 49(7), 968-993.

McGarry, O. (2015). Repositioning the research encounter: Exploring power dynamics and positionality in youth research. International Journal of Social Research Methodology, 19(3), 339-354.

Mierina, I., \& Koroleva, I. (2015). Support for far right ideology and anti-migrant attitudes among youth in Europe: A comparative analysis. The Sociological Review, 63, 183-205.

Miles, S. (2015). Young people, consumer citizenship and protest: The problem with romanticizing the relationship to social change. Young, 23(2), 101-115.

Norris, P. (Ed.). (1999). Critical citizens: Global support for democratic government. Oxford: Oxford University Press.

Norris, P. (2001). Digital divide: Civic engagement, information poverty, and the Internet worldwide. Cambridge: Cambridge University Press.

Norris, P. (2002a). Tuned out voters? Ethical Perspectives, 9(4), 200-221.

Norris, P. (2002b). Democratic phoenix: Reinventing political activism. Cambridge: Cambridge University Press.

Norris, P. (2003). Young people and political activism: From the politics of loyalties to the politics of choice? Report for the Council of Europe Symposium, Mimeo, Harvard University.

O’Dwyer, E., Lyons, E., \& Cohrs, J. (2015). How Irish citizens negotiate foreign policy: A social representations approach to neutrality. Political Psychology, 37(2), 165-181.

O'Toole, T. (2003). Engaging with young people's conceptions of the political. Children's Geographies, 1(1), 71-90.

O’Toole, T., Lister, M., Marsh, D., Jones, S., \& McDonough, A. (2003). Tuning out or left out? Participation and non-participation among young people. Contemporary Politics, 9(1), 45-61.

Persad, G. C. (2016). Expanding deliberation in critical-care policy design. The American Journal of Bioethics, 16(1), 60-63.

Rodríguez López, M., Andreouli, E., \& Howarth, C. (2015). From ex-combatants to citizens: Connecting everyday citizenship and social reintegration in Colombia. Journal of Social and Political Psychology, 3(2), 171-191.

Rowe, P. (2015). MamaBakers as everyday makers: The political is personal. Policy Studies, 36(6), 623-639.

Smith, G. (2016). Against social democratic angst about revolution: From failed citizens to critical praxis. Dialectical Anthropology, 40(3), 221-239.

Vorhaus, J. (2015). Dignity, capability, and profound disability. Metaphilosophy, 46(3), 462-478.

Vromen, A. (2008). Inclusion through voice: Youth participation in government and community decision-making. In Social Inclusion and Youth Workshop Proceedings, Brotherhood of St Laurence, Melbourne. 
Vromen, A., Loader, B., Xenos, M., \& Bailo, F. (2016). Everyday making through face book engagement: Young citizens' political interactions in Australia, the United Kingdom and the United States. Political Studies, 64(3), 513-533.

Wurgler, E., \& Brooks, C. (2014). Out of step? Voters and social issues in U.S. presidential elections. The Sociological Quarterly, 55(4), 683-704.

Zuckerman, E. (2014). New media, new civics? Policy \& Internet, 6(2), 151-168. 